\title{
Micromonospora aurantionigra sp. nov., Isolated from a Peat Swamp Forest in Thailand
}

\author{
Chitti Thawai ${ }^{1,3}$, Somboon Tanasupawat ${ }^{1 *}$, Takashi Itoh $^{3}$, \\ Khanit Suwanborirux ${ }^{2}$ and Takuji Kudo ${ }^{3}$ \\ ${ }^{1}$ Department of Microbiology and ${ }^{2}$ Department of Pharmacognosy, Faculty of Pharmaceutical Sciences, \\ Chulalongkorn University, Bangkok 10330, Thailand \\ ${ }^{3}$ Japan Collection of Microorganisms, RIKEN (The Institute of Physical and Chemical Research), \\ Wako, Saitama 351-0198, Japan \\ (Received Apr. 7, 2004 / Accepted Apr. 30, 2004)
}

\begin{abstract}
Actinomycete strain TT1-11 , which produces single non-motile spores on substrate hyphae, was isolated from peat swamp forest soil in Thailand. The isolate showed morphological and chemotaxonomic properties consistent with its classification in the genus Micromonospora. Phylogenetic analysis using 16S rDNA sequences supported this assignment and it formed a subclade with $M$. coerulea. This isolate can be distinguished from $M$. coerulea by its physiological and biochemical properties, and it showed a less than 53\% DNA relatedness to the type strains of all the validly named Micromonospora species. On the basis of phenotypic, genotypic and phylogenetic data, strain TT1-11 $\left(=\mathrm{JCM} 12357^{\mathrm{T}}=\mathrm{PCU} 239^{\mathrm{T}}=\mathrm{DSM}\right.$ $44815^{\mathrm{T}}=$ TISTR $1232^{\mathrm{T}}$ ) is proposed as the type strain of a novel Micromonospora species, Micromonospora aurantionigra sp. nov.
\end{abstract}

\section{INTRODUCTION}

The genus Micromonospora was first described by $\emptyset$ rskov $^{1)}$ for an actinomycete that produces non-motile spores borne singly on sporophores branched from substrate hyphae. This genus is well established according to its morphological and chemotaxonomic characteristics ${ }^{2-4)}$ as well as through $16 \mathrm{~S}$ rDNA-based phylogenetic analy$\operatorname{ses}^{5)}$.

In the Approved Lists of Bacterial Names ${ }^{6)}, 12$ species and 7 subspecies were cited as members of the genus Micromonospora, and Micromonospora olivasterospora ${ }^{7}$, M. rosaria $a^{8)}$ and $M$. chersina ${ }^{9)}$ were later validly proposed as new species. Lee et al. ${ }^{10)}$ transferred Catellatospora matsumotoense to the genus Micromonospora as M. matsumotoense on the basis of 16S rDNA analysis. Recently, reclassification at the species level of the genus Micromonospora was carried out by Kasai et al. ${ }^{11)}$ on the basis of $g y r B$ sequence analyses and DNA-DNA hybridization experiments. They reclassified the members of Micromonospora into the following 14 species: M. aurantiaca, M. carbonacea, M. chalcea, M. chersina, M. coerulea, M. echinospora, M. gallica, M. halophytica, M. inositola, M. nigra, M. olivasterospora, M. pallida, M. purpureochromogenes and $M$. rosaria. Consequently, at present, the genus Micromonospora is thought to accommodate 15 species, that is, the 14 species reclassified by Kasai et al. and $M$. matsumotoense. According to Kawamoto ${ }^{12)}$, the type strain of M. gallica (NTCT $4582^{\mathrm{T}}$ ) is no longer available.

In the course of investigations of novel actinomycetes from peat swamp forest soil in southern Thailand, we isolated strain TT1-11 ${ }^{\mathrm{T}}$ showing unique phenotypic charac- teristics that differ from all known type strains of the genus Micromonospora. Based on polyphasic taxonomic study, this isolate was shown to be a novel species of the genus Micromonospora, for which the name Micromonospora aurantionigra sp. nov. is proposed.

\section{MATERIALS AND METHODS}

\section{Microorganisms and culture conditions}

Strain TT1- $11^{\mathrm{T}}$ was obtained from a soil sample collected in a peat swamp forest in Thatien, Pattalung, Thailand and isolated on starch-casein nitrate agar after incubation at $30^{\circ} \mathrm{C}$ for 21 days. The colonies of this strain were purified on yeast extract-malt extract agar (ISP medium no. 2) and maintained on the same medium as a working culture. The 14 type strains of all the validly described species of the genus Micromonospora, except for M. gallica, were obtained from the Japan Collection of Microorganisms (JCM).

\section{Morphology}

Strain TT1 $11^{\mathrm{T}}$ was grown on ISP medium no. 2 at $30^{\circ} \mathrm{C}$ for 14 days then observed by light and scanning electron microscopes (model JSM-5410 LV; JEOL, Ltd., Tokyo, Japan). The sample for scanning electron microscopy was prepared by cutting a block from an agar plate, then fixing it with $1 \% \mathrm{OsO}_{4}$ in $0.1 \mathrm{M}$ phosphate buffer $(\mathrm{pH} 7.2$ ) at room temperature for $4 \mathrm{~h}$. The samples were dehydrated in a graded series of ethanol and dried with a critical point dryer (model Samdri-780, Balzers CPD 020). It was then placed onto a stub bearing adhesive and spatter-coated with gold under a vacuum ${ }^{13)}$.

*Corresponding author. Phone: +662-218-8376. Fax: +662-255-8227. E-mail: Somboon.T@Chula.ac.th 
Cultural, physiological and biochemical characteristics

The phenotypic properties were examined using several standard methods; cultural characteristics were tested using 14-day cultures grown at $30^{\circ} \mathrm{C}$ on various agar media (Table 1). The Jacal Color Card L2200 (Japan Color Research Institute) was used to determine the color designations and names. The decomposition of various compounds was examined using the basal medium recommended by Gordon et al. ${ }^{14)}$ The temperature range for growth and tolerance to $\mathrm{NaCl}$ was determined on ISP medium no. 2. Carbon source utilization was tested using ISP medium no. $9^{15)}$ supplemented with $1 \%(\mathrm{w} / \mathrm{v})$ carbon sources and $0.05 \%(\mathrm{w} / \mathrm{v})$ casamino acids. Gelatin liquefaction, milk peptonization, nitrate reduction and starch hydrolysis were determined as described by Arai ${ }^{16)}$, and Williams \& Cross $^{17)}$. Melanoid pigment production was examined in the slants of tyrosine and peptone-iron agars supplemented with $0.1 \%$ (w/v) yeast extract.

\section{Chemotaxonomic characteristics}

The freeze-dried cells used for chemotaxonomic analyses were obtained from cultures grown in yeast extractmalt extract broth (containing $0.4 \%$ glucose, $0.4 \%$ yeast extract and $1 \%$ malt extract; $\mathrm{pH} 7.3$ ) on a rotary shaker at $30^{\circ} \mathrm{C}$. Cell wall peptidoglycan was prepared and hydrolyzed according to the methods of Kawamoto et al. ${ }^{18)}$, and amino acid composition was analyzed with an automatic amino acid analyzer. The isomers of diaminopimelic acid $\left(\mathrm{A}_{2} \mathrm{pm}\right)$ in the cell walls were determined according to the method of Staneck \& Roberts ${ }^{19)}$, and the acyl group of muramic acid in the peptidoglycan was determined according to the method of Uchida \& Aida $^{20)}$. The reducing sugars from the whole-cell hydrolysates were analyzed according to the HPLC method of Mikami \& Ishida ${ }^{21)}$, and the phospholipids were extracted and analyzed according to the method of Minnikin et al. ${ }^{22)}$ Fatty acid methyl ester analysis was performed by GLC according to the instructions of the Microbial Identification System (MIDI) ${ }^{23-24)}$. Isoprenoid quinones were extracted according to the method of Collins et $a .^{25)}$ and analyzed with HPLC equipped with a Cosmosil $5 \mathrm{C}_{18}$ column (4.6 by $150 \mathrm{~mm}$; Nacalai Tesque, Kyoto, Japan). A mixture of methanol and 2-propanol (2:1, $\mathrm{v} / \mathrm{v})$ was used as the elution solvent.
Preparation of DNA, DNA base composition and DNADNA hybridization

Chromosomal DNA was extracted from cells grown in yeast extract-malt extract broth according to the method of Tamaoka ${ }^{26)}$. The $\mathrm{G}+\mathrm{C}$ content of the DNA was determined using the HPLC method of Tamaoka and Komagata $^{27)}$. An equimolar mixture of nucleotides for analysis of DNA base composition (Yamasa Shoyu, Choshi, Japan) was used as the quantitative standard. DNA-DNA relatedness was measured fluorometrically using the microplate hybridization method devised by Ezaki et al. ${ }^{28)}$
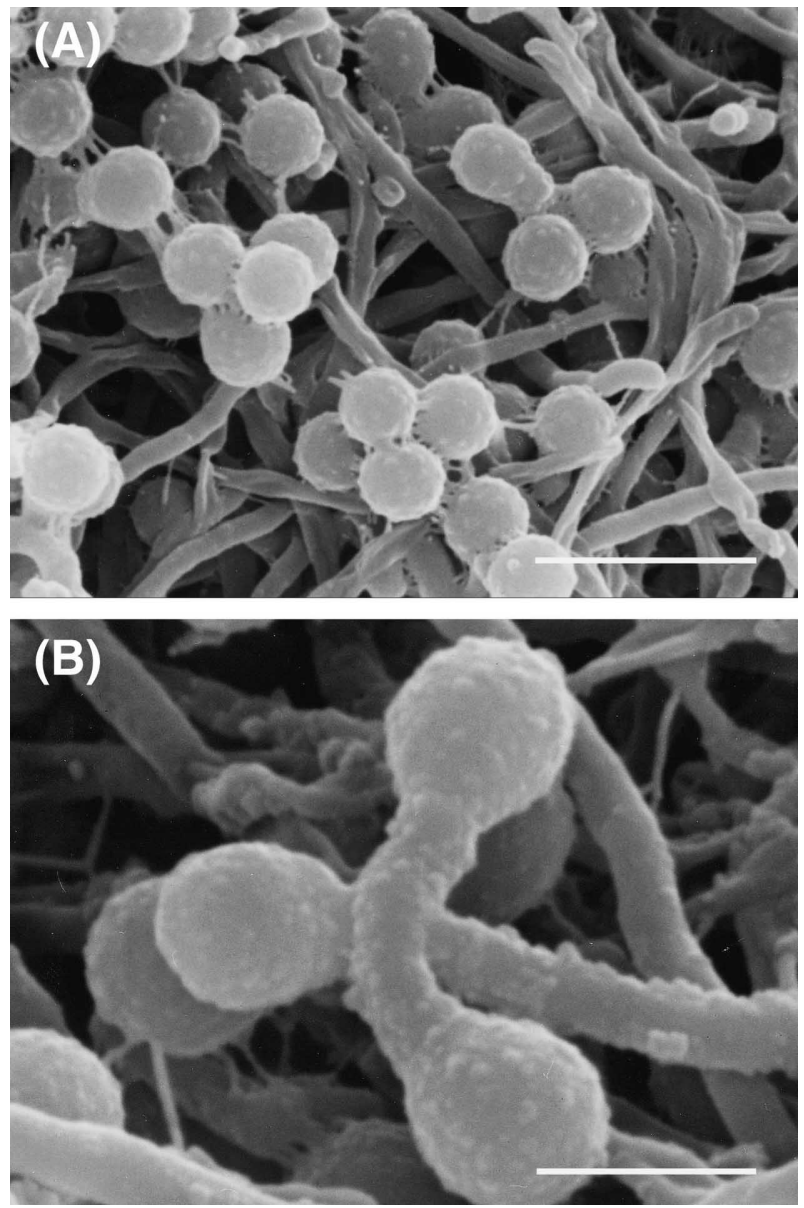

Fig. 1. Scanning electron micrographs of strain TT1-11 $1^{\mathrm{T}}$ grown on yeast extract-malt extract agar at $30^{\circ} \mathrm{C}$ for 14 days.

(A) Bar, $1 \mu \mathrm{m}$, (B) Bar, $2 \mu \mathrm{m}$.

Table 1. Cultural characteristics of strain TT1-11 ${ }^{\mathrm{T}}$.

\begin{tabular}{lccc}
\hline \multicolumn{1}{c}{ Medium } & Growth & Color of colony & Soluble pigment \\
\hline Yeast extract-malt extract agar (ISP medium no. 2) & Abundant & Brownish black to black & Brown \\
Oatmeal agar (ISP medium no. 3) & Abundant & Brownish black & None \\
Inorganic salts-starch agar (ISP medium no. 4) & Good & Orange to brownish black & None \\
Glycerol-asparagine agar (ISP medium no. 5) & Poor & Orange & None \\
Glucose-asparagine agar & Poor & Orange & None \\
Czapek's agar & Abundant & Orange & None \\
Nutrient agar & Moderate & Dark orange & None \\
\hline
\end{tabular}




\section{PCR amplification of the 16S rDNA and sequence analysis}

Genomic DNA extraction, PCR-mediated amplification of the 16S rRNA gene, and sequencing of the PCR products were carried out as described by Nakajima et al. ${ }^{29}$ The sequence was aligned with selected sequences obtained from the GenBank/EMBL/DDBJ databases using CLUSTAL $\mathrm{W}$ version 1.81 . The alignment was manually verified and adjusted prior to the construction of a phylogenetic tree, which was constructed by using the neighbor-joining ${ }^{30)}$ and maximum parsimony ${ }^{31)}$ methods in the MEGA program version $2.1^{32}$. The confidence values of the phylogenetic tree branches were determined using bootstrap analyses ${ }^{33)}$ based on 1000 resamplings. The sequence similarity values among the close strains were calculated manually after pairwise alignments obtained using the CLUSTAL X program ${ }^{34}$. Gaps and ambiguous nucleotides were eliminated from the calculations.

\section{Nucleotide sequence accession numbers}

The DDBJ accession number for the $16 \mathrm{~S}$ rDNA sequence of strain $\mathrm{TT} 1-11^{\mathrm{T}}$ is $\mathrm{AB} 159779$.

\section{RESULTS}

\section{Morphology}

Strain TT1-11 ${ }^{\mathrm{T}}$ produced well-developed and branched substrate hyphae on ISP medium no. 2 but no aerial hyphae. Spores were borne singly on the tips of sporophores produced on substrate hyphae, and were spherical in shape, rough on the surface (Fig. 1), and nonmotile.

\section{Cultural characteristics}

As shown in Table 1, strain TT1-11 $1^{\mathrm{T}}$ grew well on ISP medium no. 2, oatmeal agar (ISP medium no. 3) and Czapek's agar. The color of the vegetative mycelium was vivid orange, turning to brownish black or black after sporulation. A brown diffusible pigment was produced in ISP medium no. 2 after incubation at $30^{\circ} \mathrm{C}$ for 21 days.

\section{Biochemical and physiological characteristics}

Strain TT1-11 ${ }^{\mathrm{T}}$ utilized D-glucose, D-melibiose, D-raffinose, salicin, lactose, D-galactose, cellobiose, D-ribose, Larabinose, D-fructose and D-xylose but not L-rhamnose, glycerol and D-mannitol. Strain TT1-11 ${ }^{\mathrm{T}}$ was positive for starch hydrolysis and gelatin liquefaction, weakly positive for milk peptonization, and negative for nitrate reduction, xanthine, hypoxanthine, tyrosine and adenine decomposition, and the formation of melanoid pigments. Good growth was observed between 25 and $30^{\circ} \mathrm{C}$. No growth was observed above $40^{\circ} \mathrm{C}$. The $\mathrm{pH}$ range for growth was 5 to 10 and the $\mathrm{NaCl}$ concentration range for growth was 0 to $2 \%$.

\section{Chemotaxonomic characteristics}

The chemotaxonomic characteristics of strain TT1- $11^{\mathrm{T}}$ coincided with those of members of the genus Micromonospora. The purified cell wall of strain TT1-11 ${ }^{\mathrm{T}}$ contained glutamic acid, glycine, alanine and $\mathrm{A}_{2} \mathrm{pm}$ in a ratio of 1.0:0.8:0.5:1.1, and the isomer of $\mathrm{A}_{2} \mathrm{pm}$ was meso accompanied by its 3-hydroxy derivative (3-OH- $\left.\mathrm{A}_{2} \mathrm{pm}\right)$. The glycolate test was positive, hence the strain has $\mathrm{N}$ glycolyl muramic acid in the peptidoglycan. The wholecell hydrolysates contained glucose, xylose, arabinose, galactose, mannose and ribose, but no rhamnose. Strain TT1- $11^{\mathrm{T}}$ was therefore characterized by cell wall type II of Lechevalier \& Lechevalier ${ }^{2)}$, peptidoglycan type A1 $\gamma^{\prime}$ of Schleifer \& Kandler $^{35)}$ and whole-cell sugar pattern D of Lechevalier \& Lechevalier ${ }^{2}$. Diphosphatidylglycerol, phosphatidylinositol, phosphatidylinositolmannosides and phosphatidylethanolamine were detected but phosphatidylcholine and glucosamine-containing phospholipids were not. (type II of Lechevalier $\mathrm{et} \mathrm{al.}{ }^{3)}$ ). The cellular fatty acid composition is shown in Table 2. The major fatty acids of strain TT1-11 ${ }^{\mathrm{T}}$ were iso- $\mathrm{C}_{16: 0}$, iso- $\mathrm{C}_{15: 0}$ and small

Table 2. Cellular fatty acid composition of strain TT1-11 ${ }^{\mathrm{T}}$.

\begin{tabular}{|c|c|}
\hline Fatty acid & Percentage of total \\
\hline \multicolumn{2}{|l|}{ Saturated fatty acids } \\
\hline$C_{12: 0}$ & 0.3 \\
\hline $\mathrm{C}_{15: 0}$ & 0.5 \\
\hline $\mathrm{C}_{16: 0}^{1 \mathrm{~S}: 0}$ & 0.7 \\
\hline $\mathrm{C}_{17.0}$ & 1.4 \\
\hline $\mathrm{C}_{18: 0}$ & 1.5 \\
\hline $\mathrm{C}_{19.0}$ & 0.3 \\
\hline \multicolumn{2}{|l|}{ Unsaturated fatty acids } \\
\hline $2 \mathrm{OH}-\mathrm{C}_{16 \cdot 1}$ & 0.6 \\
\hline$C_{17: 1} \omega 8 c^{10: 1}$ & 1.5 \\
\hline$C_{18.1}^{1} \omega 9 \mathrm{c}$ & 1.1 \\
\hline \multicolumn{2}{|l|}{ Branched fatty acids } \\
\hline $\mathrm{i}-\mathrm{C}_{10 \cdot 0}$ & 0.3 \\
\hline $\mathrm{i}-\mathrm{C}_{12: 0}$ & 0.8 \\
\hline $\mathrm{i}-\mathrm{C}_{13: 0}$ & 0.3 \\
\hline $\mathrm{i}-\mathrm{C}_{14: 0}$ & 3.5 \\
\hline $\mathrm{i}-\mathrm{C}_{15: 0}$ & 11.5 \\
\hline $\mathrm{a}-\mathrm{C}_{15: 0}$ & 4.6 \\
\hline $\mathrm{i}-\mathrm{C}_{15: 1}$ & 1.0 \\
\hline $\mathrm{i}-\mathrm{C}_{16 \cdot 0}$ & 39.1 \\
\hline $\mathrm{i}-\mathrm{C}_{16: 1}^{10: 0}$ & 9.5 \\
\hline $3 \mathrm{OH}-\mathrm{i}-\mathrm{C}_{16: 0}$ & 0.2 \\
\hline $\mathrm{i}-\mathrm{C}_{1770}$ & 4.7 \\
\hline$a-C_{17 \cdot 0}$ & 5.8 \\
\hline $\mathrm{i}-\mathrm{C}_{18: 0}$ & 1.9 \\
\hline $\mathrm{i}-\mathrm{C}_{17.1} \omega 9 \mathrm{c}$ & 2.7 \\
\hline$a-C_{17: 1} \omega 9 c$ & 1.4 \\
\hline \multicolumn{2}{|l|}{ 10-Methyl fatty acids } \\
\hline $10-\mathrm{Me} \mathrm{C}_{17: 0}$ & 2.4 \\
\hline $10-\mathrm{Me} \mathrm{C} \mathrm{C}_{18.0}(\mathrm{TBSA})$ & 0.9 \\
\hline Summed feature $3^{\mathrm{a}}$ & 0.3 \\
\hline Summed feature $6^{\mathrm{a}}$ & 0.1 \\
\hline
\end{tabular}

${ }^{a}$ Summed features 3 contains $\mathrm{C} 16: 1 \omega 7 \mathrm{c}$ and/or $\mathrm{C} 15: 0$ iso 2-OH; summed features 6 contains $\mathrm{C} 19: 1 \omega 11 \mathrm{c}$ and/or C19:1 $19 \mathrm{c}$. 
amount of iso- $\mathrm{C}_{17: 0}$, anteiso- $\mathrm{C}_{17: 0}$, anteiso- $\mathrm{C}_{15: 0}$ were also present. This pattern corresponds to fatty acid type $3 \mathrm{~b}$ of Kroppenstedt ${ }^{4)}$. Mycolic acids were absent. The major menaquinones were MK-10 $\left(\mathrm{H}_{4}\right)(55 \%)$, MK-9 $\left(\mathrm{H}_{4}\right)(16 \%)$, MK-10 $\left(\mathrm{H}_{6}\right)(11 \%)$, and small amounts of MK-9 $\left(\mathrm{H}_{6}\right)$, MK$10\left(\mathrm{H}_{2}\right), \mathrm{MK}-10\left(\mathrm{H}_{8}\right)$ and MK-9 $\left(\mathrm{H}_{2}\right)$ were also present. The $\mathrm{G}+\mathrm{C}$ content of the DNA was $72.8 \mathrm{~mol} \%$.

\section{Phylogenetic analysis}

An almost complete $16 \mathrm{~S}$ rDNA sequence comprising of 1,482 nucleotides was determined for strain TT1-11 ${ }^{\mathrm{T}}$ and its 1,426 nucleotides were used for phylogenetic analysis. The strain showed more than $98.0 \%$ similarity to members of the genus Micromonospora. Of the type strains of the 14 validly named Micromonospora species, $M$. coerulea (98.7\%) showed the highest $16 \mathrm{~S}$ rDNA similarity to strain TT1-11 ${ }^{\mathrm{T}}$. The sequence of strain TT1-11 ${ }^{\mathrm{T}}$ was compared with the corresponding $16 \mathrm{~S}$ rDNA sequences of all the type strains validly described as Micromonospora species, except for $M$. gallica, as well as with selected members of the genus Actinoplanes and Streptomyces ambofaciens (as an outgroup). As a result, the isolate formed a clade with $M$. coerulea but this was not supported by a high
Table 3. DNA base composition and DNA-DNA relatedness between strain TT1-11 $11^{\mathrm{T}}$ and type strains of validly described Micromonospora species.

\begin{tabular}{|c|c|c|}
\hline \multicolumn{2}{|c|}{$\begin{array}{l}\mathrm{G}+\mathrm{C} \text { content } \\
\quad(\mathrm{mol} \%)\end{array}$} & \multirow{2}{*}{$\begin{array}{c}\text { Percentage DNA com- } \\
\text { plementarity with } \\
\text { labeled DNA from } \\
\text { strain TT1-11 } \\
100\end{array}$} \\
\hline $\mathrm{TT} 1-11^{\mathrm{T}}$ & 72.8 & \\
\hline M. chersina $\mathrm{JCM} 9459^{\mathrm{T}}$ & 72.9 & 48 \\
\hline M. coerulea $\mathrm{JCM} 3175^{\mathrm{T}}$ & 71.7 & 37 \\
\hline $\begin{array}{l}\text { M. purpureochromogenes } \\
\text { JCM } 3156^{\mathrm{T}}\end{array}$ & 73.0 & 43 \\
\hline M. echinospora JCM $3073^{\mathrm{T}}$ & 71.7 & 33 \\
\hline M. carbonacea JCM $3139^{\mathrm{T}}$ & 73.3 & 32 \\
\hline M. chalcea $\mathrm{JCM} 3031^{\mathrm{T}}$ & 71.9 & 41 \\
\hline M. inositola JCM $6239^{\mathrm{T}}$ & 71.4 & 38 \\
\hline M. olivasterospora JCM $7348^{\mathrm{T}}$ & 71.9 & 35 \\
\hline M. nigra JCM $8973^{\mathrm{T}}$ & 71.7 & 37 \\
\hline M. halophytica JCM $3125^{\mathrm{T}}$ & 72.5 & 53 \\
\hline M. aurantiaca JCM $10878^{\mathrm{T}}$ & 71.6 & 40 \\
\hline M. rosaria $\mathrm{JCM} 3159^{\mathrm{T}}$ & 72.9 & 34 \\
\hline M. matsumotoense JCM $9104^{\mathrm{T}}$ & 71.0 & 32 \\
\hline M. pallida JCM $3133^{\mathrm{T}}$ & 71.1 & 35 \\
\hline
\end{tabular}

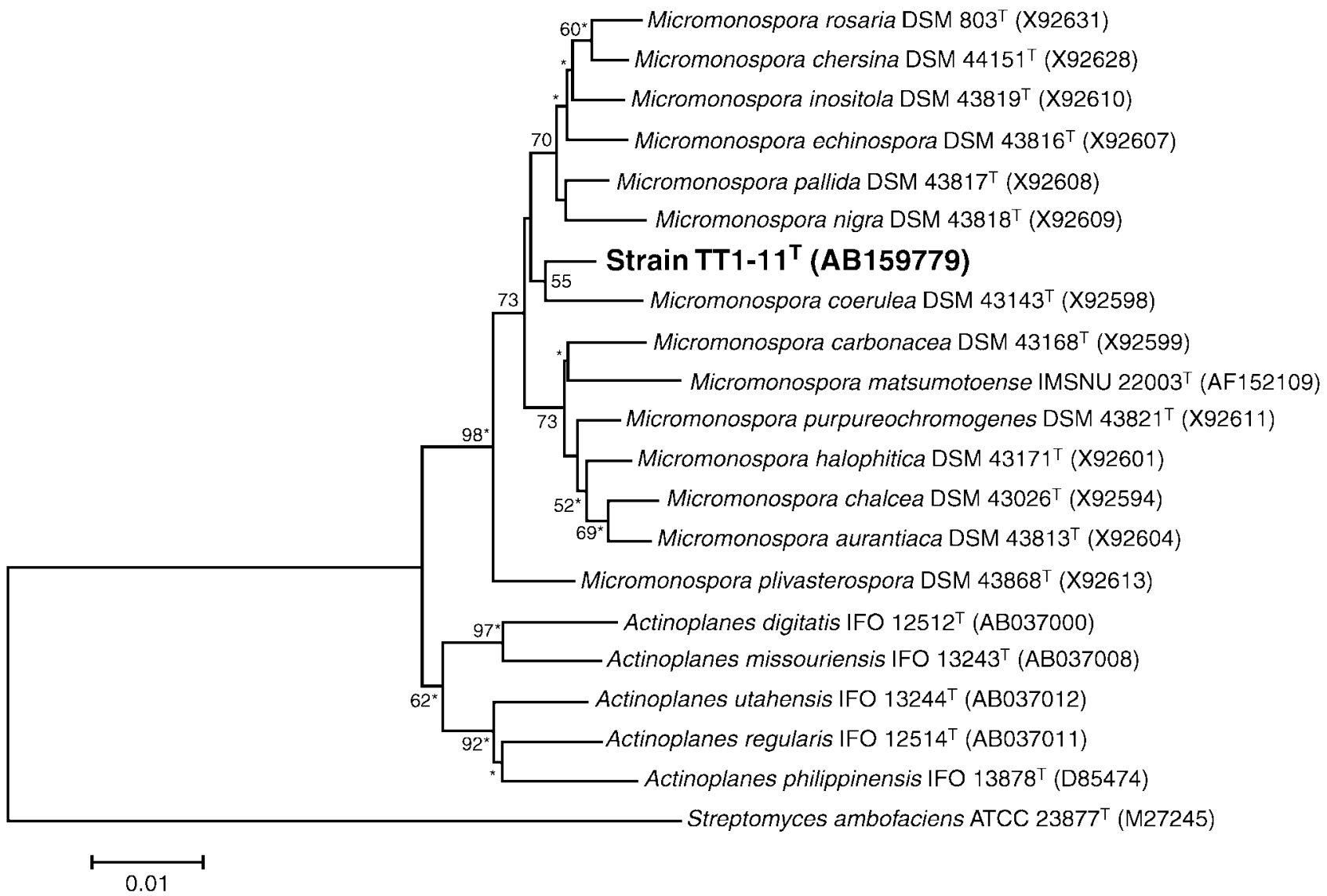

Fig. 2. Neighbour-joining tre ${ }^{30)}$ based on almost-complete $16 \mathrm{~S}$ rDNA sequences showing relationships among strain TT1-11 ${ }^{\mathrm{T}}$, the 14 validly described Micromonospora species and selected type strains of the genus Actinoplanes.

Streptomyces ambofaciens is used as the outgroup. Asterisks indicate branches of the tree that were also found in the tree constructed using the maximum-parsimony method ${ }^{31)}$. The numbers on the branches indicate the percentage bootstrap values of 1000 replicates (only values $>50 \%$ are indicated). Bar, 0.01 substitutions per nucleotide position. 
Table 4. Differential physiological and biochemical characteristics of strain TT1-11 $1^{\mathrm{T}}$ and the type strains of the genus Micromonospora having hydrogenated MK-10 as predominant isoprenoid quinones.

\begin{tabular}{|c|c|c|c|c|c|c|c|c|c|c|}
\hline \multirow{2}{*}{ Characteristic $^{a}$} & \multicolumn{10}{|c|}{ Strain $^{\mathrm{b}}$} \\
\hline & 1 & 2 & 3 & 4 & 5 & 6 & 7 & 8 & 9 & 10 \\
\hline Nitrate reduction & - & - & - & - & + & - & - & - & - & + \\
\hline Peptonization of milk & $\mathrm{w}$ & + & + & - & $\mathrm{w}$ & + & + & + & + & + \\
\hline Starch hydrolysis & + & + & + & $\mathrm{w}$ & - & + & + & + & + & - \\
\hline \multicolumn{11}{|l|}{ Decomposition of: } \\
\hline Tyrosine & - & - & - & - & - & - & - & - & - & + \\
\hline \multicolumn{11}{|l|}{ Growth at: } \\
\hline $10^{\circ} \mathrm{C}$ & - & + & - & - & + & - & - & + & - & - \\
\hline $12^{\circ} \mathrm{C}$ & + & + & - & + & + & - & - & + & - & + \\
\hline Maximum $\mathrm{NaCl}$ tolerance & $2 \%$ & $1.5 \%$ & $5 \%$ & $1.5 \%$ & $1.5 \%$ & $3 \%$ & $3 \%$ & $3 \%$ & $2 \%$ & $4 \%$ \\
\hline \multicolumn{11}{|l|}{ Utilization of: } \\
\hline D-Mannitol & - & - & - & - & - & - & - & - & + & - \\
\hline D-Ribose & + & - & - & - & - & - & $\mathrm{w}$ & $\mathrm{w}$ & $\mathrm{w}$ & - \\
\hline L-Rhamnose & - & - & - & - & - & + & - & - & + & - \\
\hline D-Melibiose & + & + & + & + & + & $\mathrm{w}$ & - & - & + & + \\
\hline D-Raffinose & + & + & + & $\mathrm{w}$ & $\mathrm{w}$ & - & - & + & - & $\mathrm{w}$ \\
\hline Glycerol & - & - & - & - & - & - & - & - & - & - \\
\hline Salicin & + & $\mathrm{w}$ & - & - & - & - & - & - & - & - \\
\hline Lactose & + & + & + & + & $\mathrm{w}$ & $\mathrm{w}$ & - & + & + & - \\
\hline D-Galactose & + & + & + & + & + & + & - & + & + & + \\
\hline L-Arabinose & + & - & $\mathrm{w}$ & - & - & + & + & + & $\mathrm{w}$ & $\mathrm{w}$ \\
\hline Cellobiose & + & + & + & + & + & + & + & + & + & + \\
\hline D-Fructose & + & + & $\mathrm{w}$ & $\mathrm{w}$ & + & + & - & + & - & + \\
\hline D-Xylose & + & + & + & + & + & + & + & + & + & + \\
\hline
\end{tabular}

${ }^{\mathrm{a}}+$, Positive; - , negative; w, weakly positive.

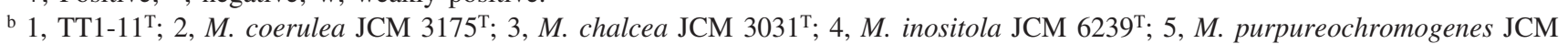
$3156^{\mathrm{T}}$; 6, M. olivasterospora JCM 7348 $;$; , M. echinospora JCM 3073 ${ }^{\mathrm{T}}$; 8, M. matsumotoense JCM 9401 ${ }^{\mathrm{T}}$; 9, M. rosaria $\mathrm{JCM}$ $3159^{\mathrm{T}} ; 10$, M. aurantiaca JCM $10878^{\mathrm{T}}$.

bootstrap value (Fig 2).

\section{DNA-DNA relatedness}

A DNA-DNA hybridization experiment was carried out between our isolate and the 14 type strains of the validly described Micromonospora species. The levels of DNADNA relatedness between strain TT1- $11^{\mathrm{T}}$ and the other type strains ranged from 32 to $53 \%$ (Table 3 ).

\section{DISCUSSION}

Strain TT1-11 ${ }^{\mathrm{T}}$ showed typical morphological and chemotaxonomic characteristics of the genus Micromonospora such as the formation of spores singly borne on substrate hyphae, cell wall type $\mathrm{II}^{35)}$, presence of $\mathrm{N}$-glycolyl muramic acid in the peptidoglycan, whole-cell sugar pattern $\mathrm{D}^{2)}$, phospholipid type $\mathrm{II}^{3)}$ and cellular fatty acid type $3 b^{4)}$. The phylogenetic data based on the $16 \mathrm{~S}$ rDNA sequences clearly supported the assignment of this strain to the genus Micromonospora. The genus Micromonospora currently consists of 15 validly described species, which (except for $M$. gallica) can be divided into three groups based on the predominant menaquinone components, namely, MK-9, MK-10 and MK-12 groups ${ }^{12)}$. Species containing hydrogenated MK-9 as the major menaquinones (MK-9 group) are M. carbonacea, M. halo- phytica, $M$. nigra ${ }^{12)}$ and $M$. chersina $^{9)}$, while the MK-12 group is composed of one species, M. pallida ${ }^{12)}$. Strain TT1-11 ${ }^{\mathrm{T}}$ belongs to the MK-10 group together with $M$. chalcea, M. inositola, M. coerulea, M. purpureochromogenes, M. olivasterospora, M. echinospora ${ }^{12)}$, M. matsumotoense $^{10)}, M$. rosaria and $M$. aurantiaca. Table 4 shows the differential physiological and biochemical characteristics of this new isolate and the type strains belonging to the MK-10 group. Strain TT1-11 ${ }^{\mathrm{T}}$ showed a different physiological and biochemical pattern compared to the other type strains belonging to the MK-10 group. In particular, the utilization of salicin effectively discriminates strain TT1-11 ${ }^{\mathrm{T}}$ from the other type strains of this group, while the utilization of L-arabinose and D-ribose differed between strain TT1-11 ${ }^{\mathrm{T}}$ and the phylogenetically closest species, $M$. coerulea. In addition, DNA relatedness values between strain TT1-11 $1^{\mathrm{T}}$ and the 14 type strains of the other validly described species were only $53 \%$ or less (Table 3). On the basis of these phenotypic and genotypic characteristics, it is suggested that strain TT1- $11^{\mathrm{T}}$ should be recognized as a novel species of the genus Micromonospora under the proposed name Micromonospora aurantionigra sp. nov. 
Description of Micromonospora aurantionigra sp. nov. Micromonospora aurantionigra (au.ran.ti.o.ni'gra. L. $\mathrm{n}$. aurum gold; L. adj. niger black; N.L. fem. adj. aurantionigra pertaining to the color of colony). Aerobic, Grampositive, mesophilic, non-motile actinomycete that forms well-developed and branched substrate hyphae. Colonies are vivid orange in ISP medium 2, turning to brownish black or black after sporulation. Single spores are formed on the substrate hyphae. Aerial mycelium is absent. The spores are non-motile and their surface appears rough. Brown soluble pigment is produced in ISP medium no. 2 . Utilizes D-glucose, D-melibiose, D-raffinose, salicin, lactose, D-galactose, cellobiose, D-ribose, L-arabinose, D-fructose and D-xylose, but not L-rhamnose, glycerol and Dmannitol. Hydrolysis of starch and gelatin liquefaction are positive, milk peptonization is weakly positive, and nitrate reduction, xanthine, hypoxanthine, tyrosine and adenine decomposition, and the production of melanin and hydrogensulfide are negative. Good growth is observed between 25 and $30^{\circ} \mathrm{C}$. No growth occurs above $40^{\circ} \mathrm{C}$. The maximum $\mathrm{NaCl}$ concentration for growth is $2 \%$. Cell wall contains glutamic acid, glycine, alanine and meso- and 3-OHdiaminopimlic acid. The acyl type of the cell wall is glycolyl. The characteristic whole-cell sugars are xylose and arabinose. The phospholipid profile contains diphosphatidylglycerol, phosphatidylinositolmannosides, phosphatidylinositol and phosphatidylethanolamine, but not phosphatidylcholine. The major cellular fatty acids are iso$\mathrm{C}_{16: 0}$ and iso- $\mathrm{C}_{15: 0}$, and a small amount of iso- $\mathrm{C}_{17: 0}$, anteiso- $\mathrm{C}_{17: 0}$ and anteiso- $\mathrm{C}_{15: 0}$ are also present. Mycolic acids are absent. The predominant menaquinones are MK$10\left(\mathrm{H}_{4}\right)$, MK- $9\left(\mathrm{H}_{4}\right)$, and MK-10 $\left(\mathrm{H}_{6}\right)$. The $\mathrm{G}+\mathrm{C}$ content of the DNA is $72.8 \mathrm{~mol} \%$. Habitat is soil. The type strain is strain TT1-11 ${ }^{\mathrm{T}}\left(=\mathrm{JCM} 12357^{\mathrm{T}}=\mathrm{PCU} 239^{\mathrm{T}}=\mathrm{DSM} 44815^{\mathrm{T}}\right.$ $=$ TISTR $\left.1532^{\mathrm{T}}\right)$.

\section{ACKNOWLEDGEMENTS}

The scholarship from the Royal Golden Jubilee Ph.D. Program to C. T. is gratefully acknowledged. We thank M. Chijimatsu and H. Morishita, Research Resources Center, the RIKEN Brain Science Institute, for analyzing amino acid composition of cell wall peptidoglycan. We thank P. Pancharoonrat for collecting the soil sample.

\section{REFERENCES}

1) Ørskov, J.: Investigations into the Morphology of the Ray Fungi. Levin and Munksgaard, Copenhagen, 1923

2) Lechevalier, M. P. \& H. A. Lechevalier: Chemical composition as a criterion in the classification of aerobic actinomycetes. Int. J. Syst. Bacteriol. 20: 435-443, 1970

3) Lechevalier, M. P.; C. DeBievre \& H. A. Lechevalier: Chemotaxonomy of aerobic actinomycetes: phospholipid composition. Biochem. Syst. Ecol. 5: 249-260, 1977

4) Kroppenstedt, R. M.: Fatty acid and menaquinone analysis of actinomycetes and related organisms. In Chemical
Methods in Bacterial Systematics. Eds., M. Goodfellow and D. E. Minnikin, pp. 173-199. Academic Press, London, 1985

5) Stackebrandt, E.; F. A. Rainey \& N. L. Ward-Rainey: Proposal for a new hierarchic classification system, Actinobacteria classis nov. Int. J. Syst. Bacteriol. 47: 479-491, 1997

6) Skerman, V. B. D.; V. McGowan \& P. H. A. Sneath: Approved lists of bacterial names. Int. J. Syst. Bacteriol. 30: 225-420, 1980

7) Kawamoto, I.; M. Yamamoto \& T. Nara: Micromonospora olivasterospora sp. nov. Int. J. Syst. Bacteriol. 33: 107-112, 1983

8) Horan, A. C. \& B. C. Brodsky: Micromonospora rosaria sp. nov., nom. rev., the rosaramicin producer. Int. J. Syst. Bacteriol. 36: 478-480, 1986

9) Tomita, K.; Y. Hoshino, N. Ohkusa, T. Tsuno \& T. Miyaki: Micromonospora chersina sp. nov. Actinomycetologica 6: 21-28, 1992

10) Lee, S. D.; M. Goodfellow \& Y. C. Hah: A phylogenetic analysis of the genus Catellatospora based on $16 \mathrm{~S}$ ribosomal DNA sequence, including transfer of Catellatospora matsumotoense to the genus Micromonospora as Micromonospora matsumotoense comb. nov. FEMS Microbiol. Lett. 178: 349-354, 1999

11) Kasai, H.; T. Tamura \& S. Harayama: Intrageneric relationships among Micromonospora species deduced from gyrB- based phylogeny and DNA relatedness. Int. J. Syst. Bacteriol. 50: 127-134, 2000

12) Kawamoto, I.: Genus Micromonospora. In Bergey's Manual of Systematic Bacteriology. vol. 4. Eds., S. T. Williams, M. E. Sharpe \& J. G. Holt, pp. 2442-2450, William \& Wilkins Press, Baltimore, 1989

13) Itoh, T.; T. Kudo, F. Parenti \& A. Seino: Amended description of the genus Kineosporia, based on chemotaxonomic and morphological studies. Int. J. Syst. Bacteriol. 39: 168-173, 1989

14) Gordon, R. E.; D. A. Barnett, J. E. Handerhan \& C. H. Pang: Nocardia coeliaca, Nocardia autotrophica, and the nocardin strain. Int. J. Syst. Bacteriol. 24: 54-63, 1974

15) Shiring, E. B. \& D. Gottlieb: Methods for characterization of Streptomyces species. Int. J. Syst. Bacteriol. 16: 313-340, 1966

16) Arai, T.: Culture Media for Actinomycetes. The Society for Actinomycetes Japan, Tpkyo, 1975

17) Williams, S. T. \& T. Cross: Actinomycetes. In Methods in Microbiology, vol. 4. Ed., C. Booth, pp. 295-334. Academic Press, London, 1971

18) Kawamoto, I.; T. Oka \& T. Nara: Cell wall composition of Micromonospora olivasterospora, Micromonospora sagamiensis, and related organisms. J. Bacteriol. 146: 527-534, 1981

19) Staneck, J. L. \& G. D. Roberts: Simplified approach to identification of aerobic actinomycetes by thin-layer chromatography. Appl. Microbiol. 28: 266-231, 1974

20) Uchida, K. \& K. Aida: An improved method for the glycolate test for simple identification of the acyl type of bacterial cell walls. J. Gen. Appl. Microbiol. 30: 131-134, 1984

21) Mikami, H. \& Y. Ishida: Post-column fluorometric detection of reducing sugar in high-performance liquid chromatography using arginine. Bunseki Kagaku 32: 
E207-E210, 1983

22) Minnikin, D. E.; A. G. O’Donnell, M. Goodfellow, G. Alderson, M. Athalye, A. Schaal \& J. H. Parlett: An integrated procedure for the extraction of bacterial isoprenoid quinines and polar lipids. J. Microbiol. Methods 2: 233-241, 1984

23) Sasser, M.: Identification of Bacteria by Gas Chromatography of Cellular Fatty Acids. Technical Note 101. MIDI, Newark, DE, 1990

24) Kämpfer, P. \& R. M. Kroppenstedt: Numerical analysis of fatty acid patterns of coryneform bacteria and related taxa. Can. J. Microbiol. 42: 989-1005, 1996

25) Collins, M. D.; T. Pirouz, M. Goodfellow \& D. E. Minnikin: Distribution of menaquinones in actinomycetes and corynebacteria. J. Gen. Microbiol. 100: 221-230, 1977

26) Tamaoka, J.: Determination of DNA Base Composition. In Chemical Methods in Prokaryotic Systematics. Eds., M. Goodfellow \& A. G. O’Donnell, pp. 463-470. John Wiley \& Sons Press, Chichester, 1994

27) Tamaoka, J. \& K. Komagata: Determination of DNA base composition by reversed-phase high-performance liquid chromatography. FEMS Microbiol. Lett. 25: 125-128, 1984

28) Ezaki, T.; Y. Hashimoto \& E. Yabuuchi: Fluorometric deoxyribonucleic acid- deoxyribonucleic acid hybridization in microdilution wells as an alternative to membrane filter hybridization in which radioisotopes are used to determine genetic relatedness among bacterial strains. Int. J. Syst. Bacteriol. 39: 224-229, 1989

29) Nakajima, Y.; V. Kitpreechavanich, K. Suzuki \& T. Kudo: Microbispora coralline sp. nov., a new species of the genus Microbispora isolated from Thai soil. Int. J. Syst. Bacteriol. 49: 1761-1767, 1999

30) Saitou, N. \& M. Nei: The neighbor-joining method: a new method for reconstructing phylogenetic trees. Mol. Biol. Evol. 4: 406-425, 1987

31) Kluge, A. G. \& F. S. Farris: Quantitative phyletics and the evolution of anurans. Syst. Zool. 18: 1-32, 1969

32) Kumar, S.; K. Tamura, I. B. Jakobsen \& M. Nei: MEGA2: molecular evolutionary genetics analysis solfware. Bioinformatics 17: 1244-1245, 2001

33) Felsenstien, J.: Confidence limits on phylogenies: an approach using the bootstrap. Evolution 39: 783-791, 1985

34) Thompson, J. D.; T. J. Gibson, F. Plewniak, F. Jeanmougin \& D. G. Higgins: The CLUSTAL_X windows interface: flexible strategies for multiple sequence alignment aided by quality analysis tools. Nucleic Acids Res. 25: 4876-4882, 1997

35) Schleifer, K. H. \& O. Kandler: Peptidoglycan types of bacterial cell walls and their taxonomic implications. Bacteriol. Rev. 36: 407-477, 1972 